\title{
Correction: All-cause mortality in adults with and without type 2 diabetes: findings from the national health monitoring in Germany
}

Rockl S, Brinks R, Baumert J, et al. All-cause mortality in adults with and without type 2 diabetes: findings from the national health monitoring in Germany. BMJ Open Diabetes Research and Care 2017;5:e000451. doi:10.1136/bmjdrc-2017-000451.

The following data sharing statement has been added:

The authors confirm that some access restrictions apply to the data underlying the findings. The data set can not be made publicly available because informed consent from study participants did not cover public deposition of data. However, the minimal data set underlying the findings is archived in the 'Health Monitoring' Research Data Centre at the Robert Koch Institute (RKI) and can be accessed by all interested researchers. On-site access to the data set is possible at the Secure Data Center of the RKI's 'Health Monitoring' Research Data Centre. Requests should be submitted to the 'Health Monitoring' Research Data Centre, Robert Koch Institute, Berlin, Germany (e-mail: fdz@rki.de).

\section{(6) \\ OPEN ACCESS}

Open Access This is an Open Access article distributed in accordance with the Creative Commons Attribution Non Commercial (CC BY-NC 4.0) license, which permits others to distribute, remix, adapt, build upon this work non-commercially, and license their derivative works on different terms, provided the original work is properly cited and the use is non-commercial. See: http://creativecommons.org/licenses/by-nc/4.0/

C Article author(s) (or their employer(s) unless otherwise stated in the text of the article) 2017. All rights reserved. No commercial use is permitted unless otherwise expressly granted.

BMJ Open Diab Res Care 2017;5:e000451corr1. doi:10.1136/bmjdrc-2017-000451corr1

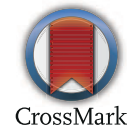

